\title{
The Relationship among Family Business, Corporate Governance, and Firm Performance: An Empirical Assessment in the Tourism Sector
}

\author{
Rossella Leopizzi ${ }^{1}$, Simone Pizzi ${ }^{2, *(D)}$ and Fabrizio D'Addario ${ }^{2}$ \\ 1 Dipartimento Jonico in Sistemi giuridici ed economici del Mediterraneo: società, ambiente, culture, \\ Università di Bari, 70121 Bari, Italy; rossella.leopizzi@uniba.it \\ 2 Dipartimento di Scienze dell'Economia, Università del Salento, 73100 Lecce, Italy; \\ fabrizio.daddario@unisalento.it \\ * Correspondence: simone.pizzi@unisalento.it
}

Citation: Leopizzi, Rossella, Simone Pizzi, and Fabrizio D'Addario. 2021. The Relationship among Family Business, Corporate Governance, and Firm Performance: An Empirical Assessment in the Tourism Sector. Administrative Sciences 11: 8. https:// doi.org/10.3390/admsci11010008

Received: 22 December 2020

Accepted: 15 January 2021

Published: 22 January 2021

Publisher's Note: MDPI stays neutral with regard to jurisdictional claims in published maps and institutional affiliations.

Copyright: (C) 2021 by the authors. Licensee MDPI, Basel, Switzerland. This article is an open access article distributed under the terms and conditions of the Creative Commons Attribution (CC BY) license (https:// creativecommons.org/licenses/by/ $4.0 /)$.

\begin{abstract}
Tourism has been the subject of great attention of policy makers. The centrality of the sector derives from multiple factors, including the high number of subjects employed within the supply chain, the contribution to developing nations' economic growth, and the environmental implications of establishing new productive activities. Under this scenario, family holdings play a central role as the main types of organisations active in the sector. In this sense, an understanding of these companies' financial performance cannot disregard the understanding of the governance mechanisms that characterize the same given the potential divergence between "family" and "business" objectives. The research aims to encourage the development of new empirical evidence about this business model, providing specific contributions regarding the role of family members in companies' decisionmaking mechanisms. For our purposes, an empirical analysis based on the evaluation of 343 Italian hotels was built.
\end{abstract}

Keywords: family business; agency theory; corporate governance; financial performance

\section{Introduction}

The past few years have seen increasing attention paid by policymakers to tourism industries (Meo et al. 2020; Alola et al. 2020). The centrality of these industries has been highlighted by tourism's central role in countries such as Italy, France, and the United Kingdom (Giaccio et al. 2018; Bagnaresi et al. 2019). An increasing number of reports underlined that investments in the cultural sector could represent enablers on citizens' wellbeing (Newell and Seabrook 2006; Palmi et al. 2016). Thus, the comprehension of the dynamics related to economic systems development based on tourism enterprises represents an exciting issue for policymakers and NGOs (Rosato et al. 2021; Mubangizi and Mwesigwa 2019).

Italy represents one of the leading European countries characterized by a high degree of tourism attractiveness. In 2019, the tourism sector represented 13\% of the Italian GDP for over 40 billion Euros (Bartoloni 2020). Furthermore, the disruptive impacts caused by COVID-19 on the tourism industry confirm the high degree of dependency on the sector.

The topic's centrality within the Italian context is related to the high number of family firms involved in tourism activities (Peters 2005). In particular, a survey conducted by the Bank of Italy highlights that a significant number of hotels are managed by family firms (Banca d'Italia 2018). In this sense, the sector is characterized by firms organized according to the Italian "modello padronale" representing a business model characterized by several criticisms. In particular, several authors discussed the main strengths and weakness related to the adoption of this organizational model (Pellicelli 2016; Illy 2019; Di Cagno et al. 2002). Prior studies on family businesses reveal different findings in terms of organizational implications related to family members' involvement. Furthermore, other studies reveal 
the existence of externalities related to the existence of non-family shareholders within organizations. Thus, scholars agreed about the opportunity to in-depth analyze family firms' characteristics (Harris and Ozdemir 2020).

The paper aims consist of the evaluation of the determinants that impact on financial performance in Tourism and Hospitality (Venkatraman and Ramanujam 1986). In particular, the analysis evaluates the impact of the family's ownership on financial performance. The choice to focus the analysis on family firms is due to their central role in the tourism sector (Getz and Carlsen 2005). Furthermore, prior studies underlined their peculiarities that are typically oriented to maximizing the family's interests (Sciascia et al. 2014; Cucculelli and Storai 2015). For our purposes, we analyzed a sample of 343 Italian hotels that exceed an overall number of 50 employees during the fiscal year 2019. In particular, we focused our analysis on the managerial implications related to ownership and governance's dynamics.

The contributions of the paper are several. Firstly, we will identify the main strengths and weakness related to adopting a business model based on the involvement of family members within the organizations. In particular, our findings will be useful for organizations and policymakers, due to the prominence of this form of business model within the European context (Venturelli et al. 2020). Furthermore, our implications will be significant for the advance of the scientific knowledge about the relationship between family business and tourism development. Despite a vast number of academics analyzed financial performance in tourism organizations, only a limited number of studies have been conducted about the moderating role covered by family members.

The paper is structured as follows: Section 2 consists of a literature review on the analysis of financial performance in the tourism sector. Section 3 introduces the theme of the family business in tourism organization, Section 4 describes the results collected within the paper while Section 5 consists of the concluding remarks.

\section{Literature Review}

\subsection{Family Business in Management Research}

During the last few years, academics have paid specific attention to the family business field (Colli 2003; Caputo et al. 2018). The relevance of the topic is connected to the peculiarities of these type of organizations. In contrast to other forms of organizations such as public companies and MNEs, family businesses are characterized by a high degree of control made by owners (Venturelli et al. 2020; De Massis et al. 2013; Sciascia et al. 2014). The strategies adopted are directly influenced by the expectative of the family about the future of the organizations. In particular, their business models usually integrate practices that the owner families need and desire (Brenes et al. 2009). Thus, the traditional framework used by management scholars to analyze organizations cannot evaluate in a reliable way the needs of family organizations to operate through paradigms characterized by the integration of "business" and "family" purposes.

The involvement of the family members within the organization can be analyzed through different perspectives. Family members can influence business strategies both as shareholders and through their governance involvement (Aguilera and Crespi-Cladera 2012; Lozano et al. 2016). In particular, several studies analyzed the different implications of family members' role within the organizations (Azila-Gbettor et al. 2018). Furthermore, other studies have shown the existence of conflicts between family and non-family members (Sakawa and Watanabel 2019; Caputo et al. 2018). In this sense, the comprehension of the internal dynamics that impact family business' financial performance requires an in-depth analysis of the corporate governance mechanisms. On the point, academics paid specific attention to different dynamics such as the generational turnover, the involvement of external members within the board of directors, and the pressures made by society on organizations' strategies (Mahto et al. 2020; Martinez Jimenez 2009; Casillas et al. 2019).

However, despite the existence of specific research about the misalignment between corporate governance and ownership structure in family organizations, many studies found a correlation between the two aspects due to family members' orientation to be part of the 
governance structure (Nordqvist et al. 2014). This evidence is related to the heterogeneity of the family business. Despite the proliferation of studies about the family business, there are different definitions of a family business. In particular, the main characteristics used by academics to classify a firm as "family business" are different due to the use of alternative proxies such as the percentage of family members involved within the board, the percentage of shares achieved by a family and the explicit reference within the brand of a family name (McGuire et al. 2012; Lude and Prügl 2018; De Massis et al. 2013).

Regarding the moderating role of family members on organizations, a vast number of empirical studies have been conducted over the years. A study conducted on a sample of 369 Spanish firms reveals that family involvement reduces the risk of business failure (Revilla et al. 2016). Another interesting perspective was provided in a study conducted on a sample of 684 Spanish and Portuguese. The study reveals that the involvement of family members impact on financial performance (Stanley et al. 2019). Furthermore, an empirical study reveals that family members' involvement is higher during the financial crisis than during period characterized by an adequate remuneration of the investments (Casillas et al. 2019). However, they integrate analysis of the main findings collected within the paper, suggesting that entrepreneurial orientation represents factors that impact firms. In particular, this evidence is relevant within the Italian context, where family members are usually involved in the decision making processes (Pellicelli 2016). Furthermore, this evidence is underlined within the Mediterranean and Italian tourism sector (Santarelli and Lotti 2005; Bagnaresi et al. 2019).

\subsection{Financial Performance in Tourism Organizations}

Numerous studies in the literature have identified the dimensions to be used to measure business performance in the tourist accommodation sector. In particular, three dimensions are identified: financial or economic, operational or competitive, and organizational or social. The financial dimension is based on mainly accounting data, such as operating profitability indicators (Yeung and Lau 2005), sales profitability (Garrigós-Simón et al. 2005) and equity profitability (Kang et al. 2010). The operating dimension concerns the company's success with its customers and is mainly measured by the employment rate (Kim and Kim 2005), the average price per room or turnover on the number of rooms sold (Chung 2000). Finally, the organizational dimension considers the satisfaction of the various corporate stakeholders, particularly property and employees (Bagnaresi et al. 2019).

The theme of the determinants of performance in hotel companies assumes a specific relevance in scholars and economic operators' dual perspective for the combination of three different reasons. First, the need to understand the particularities of hotel companies' specific performance has been reflected in the growing importance that has taken, in recent years, the tourism sector-accommodation for the different world economies (Rosato et al. 2021). This has resulted in a renewed commitment to analyze the competitive dynamics of the sector and encourage processes of dissemination of best practices associated with the management of such realities that can increase the managerial rate. Secondly, this need is reflected in the recognized economic and management specificities of hotel businesses. It is, in fact, a capital intensive business with fixed production capacity (Newell and Seabrook 2006). Also, demand assumes increasing levels of interpretative complexity in the function of the varying requirements and the tourists' differentiated behaviors to which it joins the importance that variable exogenous and not controllable from the system of the offer assume in influencing its course in time (Song and Li 2008; Brida and Risso 2010).

Moreover, the specific business's capital-intensive nature is associated with the acknowledged importance of human resources, especially those engaged in front-office activities, in the construction and concrete delivery of the guest experience (Jolliffe and Farnsworth 2003; Kusluvan et al. 2010). Finally, the need for reflection on the determinants of performance in the hotel sector is reflected in the specific importance that the destination on which insists the Hotel takes in determining its competitiveness (Zhou et al. 2015; 
Brent Ritchie and Crouch 2004). The competitiveness of hotels is strongly influenced by the level of attractiveness of the specific destination. The choice of the specific tourist accommodation shall be made, for different demand segments, only after the destination has been chosen (Sharma et al. 2018). This means that the hotel company is called, in the first instance, to collaborate with all the different actors of the destination to increase its attractiveness and, at a later time, to compete with the other structures of the destination to acquire the clientele that, All together, they helped acquire for the specific destination. This is a specific form of "co-opetition" typical of the tourist-receptive sector (Sainaghi 2004; Rosato et al. 2021).

\section{Theoretical Framework and Hypothesis Development}

The relationship between corporate governance and firms' financial performance has been analyzed in depth by academics. Since the preliminary reflections made by Berle and Means in 1932, academics have discussed the effects related to the separation between ownership and management (Van den Berghe and Carchon 2003; Shapiro 2005). The need to analyze this phenomenon is related to the complexities related to the comprehension of the procedures used by owners to control their organizations. In this sense, several studies have been conducted to identify possible implications related to the impacts related to identifying operational paradigms useful for organizations to control and manage their financial performance.

The Agency theory represents one of the main theoretical frameworks used by academics to analyze the impacts caused by the involvement of family members within organizations. Building on prior studies (Besanko et al. 2000; Fama and Jensen 1983, 2019), Van den Berghe and Carchon describes the Agency theory as a paradigm used "to analyze the problems that can arise in any cooperative exchange when one party (the "principal") contracts with another (the "agent") to make decisions on behalf of the principal". In particular, the authors connected the theory to the family business's specific field, which represents a theoretical debate characterized by a high degree of asymmetric information between family and non-family members. In this sense, family members' involvement within the decision-making processes can represent a barrier toward implementing strategies based on the needs to sustain the organizations' development. Family members can impact financial performance by implementing strategies based on protecting and sustaining family interests (Brenes et al. 2009).

According to this evidence, the paper aims to evaluate the moderating role covered by family members on the financial performance achieved by tourism organizations. In particular, following the methodological approach used in prior studies about corporate governance (Venturelli et al. 2020; De Massis et al. 2013), we conducted an analysis based on the separate evaluation of the impacts related to the involvement of family members within the corporate governance and the role of ownership structures. In detail, we will address the following research questions:

RQ1: What are the contributions of family members on Hotels' performance?

RQ2: What are the relationship between ownership's concentration and Hotels' performance?

RQ3: What are the relationship between the family's ownership and Hotels' performance?

RQ4: What are the impacts related to the inclusion of family members within the BoDs?

\section{Sampling and Methods}

The analysis was conducted on a set of multidimensional indicators to evaluate the different impacts caused by a family member on firms' performance. The choice to adopt different indicators follows as evidenced in prior studies about value creation (Caputo et al. 2014; Rai 2016). In particular, the research consists of an empirical analysis conducted on a sample of 343 Italian Hotel (Figure 1). The 343 Hotel represents the entire population of Hotels with more than 50 employees included in the AIDA database that 
has published financial statements in 2019. The choice to include only the Hotel with more than 50 employees has been driven by the exigence to analyze a sample of comparable firms. Thus, the exclusion of microenterprises avoids the risks related to the analysis of non-comparable data.

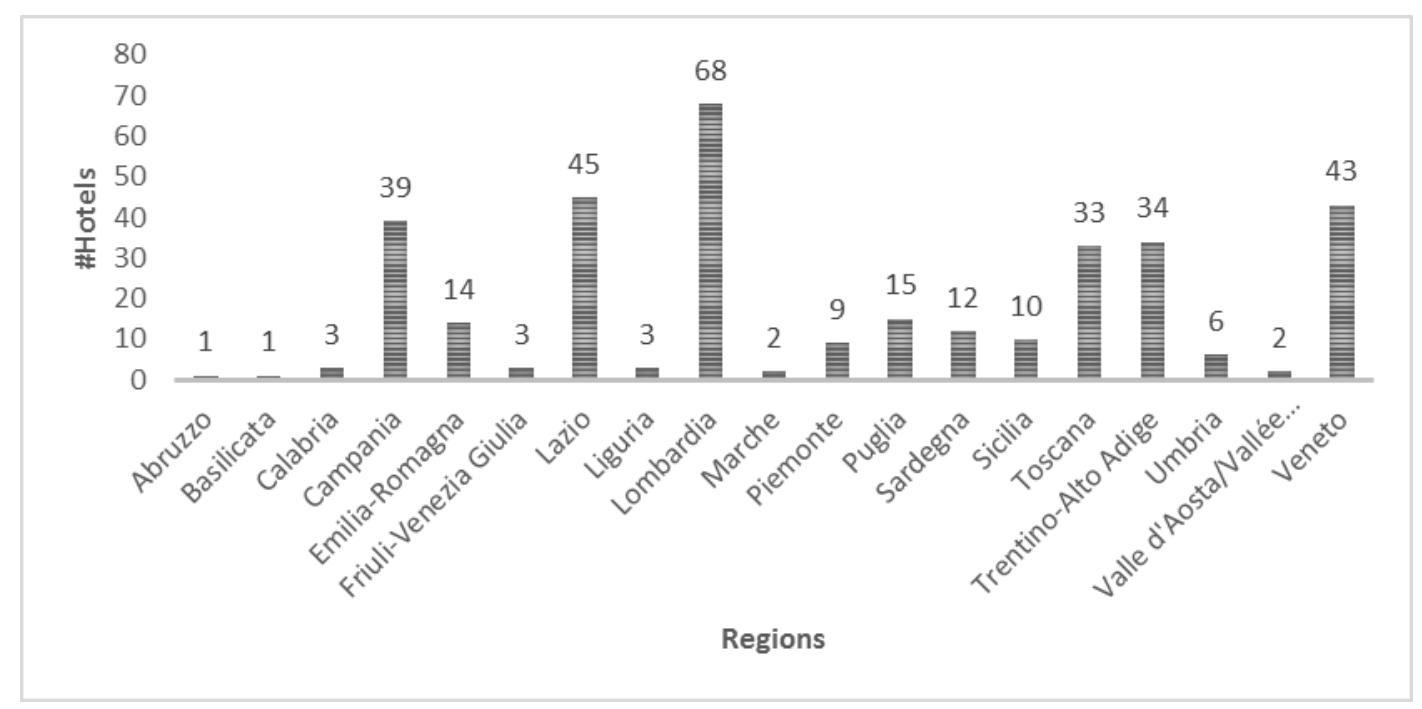

Figure 1. Sample description. Regional-level analysis. Source: Our elaboration on data extracted from AIDA BvD.

The analysis has been conducted through a quantitative approach based on OLS regressions (Pandikasala et al. 2020; Saif Ul Islam et al. 2020). The OLS represents one of the leading research methods adopted by accounting scholars to test a hypothesis based on the combination of factors (Leone et al. 2019; Stone and Rasp 1991). The empirical model was built by Saif Ul Islamwas using a dependent variable with independent and control variables based on firms' characteristics. In detail, the independent variables represent organizational factors, while control variables have been used to avoid the risks of non-reliability.

$$
\text { Financial performance }_{i}=\text { organizational factors }_{i}+\text { control variables }_{i}+e
$$

The analysis was conducted through the use of several dependent variables (Table 1). The choice to operate through the analysis of different indicators is related to evaluating different dimensions of financial performance (Van Looy and Shafagatova 2016). In particular, we used financial indicators and rating released by external providers. Furthermore, the choice has also been driven by the exigence to avoid the risks related to the analysis of indicators influenced by firms' size. In this sense, the ratio analysis represents a more effective research method than the traditional analysis of moving (Nissim and Penman 2001; Pizzi et al. 2020).

Table 1. Dependent variables description.

\begin{tabular}{|c|c|c|}
\hline Var. & Description & Expected Sign \\
\hline $\mathrm{ROE}$ & $\begin{array}{l}\text { ROE is equal to a fiscal year net income (after preferred stock dividends, before ordinary } \\
\text { stock dividends), divided by total equity (excluding preferred shares) }\end{array}$ & + \\
\hline ROA & $\begin{array}{l}\text { ROA is equal to fiscal year net income (after preferred stock dividends, before ordinary stock } \\
\text { dividends), divided by the total asset (excluding preferred shares) }\end{array}$ & + \\
\hline FALCON & FALCON measures the ability to meet future obligations & - \\
\hline CRIF & $\begin{array}{l}\text { CRIF gives each company a score of } 1000 \text { to } 1 \text {, where } 1000 \text { indicates the most stable } \\
\text { companies and one the most vulnerable. }\end{array}$ & + \\
\hline VADIS & VADIS measures the propensity for a company to be bankrupt within the next 18 months. & - \\
\hline
\end{tabular}


The dependent variables used within the study were extracted from AIDA, which represents one of the leading database used by academics to evaluate financial and nonfinancial performance of Italian organizations. In detail, we extracted from the database a set of ratios to evaluate through alternative lens the performance of the 343 organizations. In fact, despite the similarities between financial ratios, prior studies agreed about the need to conduct different analysis in studies about the relationship between financial performance and organizations' characteristics (Pizzi et al. 2020).

According to this evidence, we considered the following variables (Table 1).

The organization factors used in the study are related to the ownership structure (Table 2). According to prior studies on family firms, we considered the majority of shareholders' characteristics (Venturelli et al. 2020; Stanley et al. 2019). In particular, we assigned 1 in the presence of firms controlled by family while 0 if not (FAMILY_FIRMS). Furthermore, we considered the percentage of shares owned by the main shareholder as a proxy of control (\%SHARES). However, to evaluate the different impacts of family and non-family firms, a variable (FAMILY_POWER) based on the product between FAMILY FIRMS and \%SHARES has been included. Finally, we considered the effects related to the involvement of family members within the Board of Directors. Thus, we assigned a value equal to 1 for firms with family members on BoD and 0 if not. Similarly to FAMILY_POWER, we included in the analysis a variable that considers the combination of family involvement and BoD (FAMILY_BOARD).

Table 2. Variables analysis.

\begin{tabular}{|c|c|c|c|c|c|}
\hline Variable & Mean & Std. Dev. & Min & Max & Source \\
\hline \multicolumn{6}{|c|}{ Dependent Variables } \\
\hline ROE & 11.27 & 25.10 & -149.65 & 125.66 & AIDA BvD \\
\hline ROA & 2.85 & 28.81 & -341.62 & 77.19 & AIDA BvD \\
\hline FALCON & 4.24 & 1.92 & 1 & 10 & AIDA BvD \\
\hline CRIF & 634.92 & 142.82 & 196 & 832 & AIDA BvD \\
\hline VADIS & 3.20 & 1.725 & 1 & 9 & AIDA BvD \\
\hline \multicolumn{6}{|c|}{ Independent Variables } \\
\hline Family firms & 0.33 & 0.47 & 0 & 1 & AIDA BvD \\
\hline$\%$ Shares & 80.42 & 27.09 & 0 & 100 & AIDA BvD \\
\hline Family_power & 31.16 & 39.69 & 0 & 100 & Our elaboration \\
\hline Family_board & 0.31 & 0.46 & 0 & 1 & Our elaboration \\
\hline \multicolumn{6}{|l|}{ Control Variables } \\
\hline SIZE & 9.52 & 1.31 & 5.67 & 13.75 & AIDA BvD \\
\hline EQUITY & 8.10 & 1.96 & 2.02 & 12.96 & AIDA BvD \\
\hline EMPLOYEES & 4.55 & 0.61 & 3.91 & 7.16 & AIDA BvD \\
\hline $\mathrm{D} / \mathrm{E}$ & 2.41 & 8.95 & -1.76 & 133.29 & AIDA BvD \\
\hline
\end{tabular}

Finally, we included three control variables in our empirical model to consider the effects of firms' characteristics. In this sense, we included the natural logarithm of the total asset (SIZE), the natural logarithm of the average number of employees involved within the organizations during the observed fiscal year (EMPLOYEES) and the ratio between total debts and equity $(\mathrm{D} / \mathrm{E})$. The need to consider different variables is related to avoiding the misalignment caused by different organizations within our sample (Venturelli et al. 2020; Pizzi et al. 2020). Furthermore, the inclusion of the D/E supports the analysis of the effects related to different financing methods (Di Cagno et al. 2002). Finally, the use of a the $\mathrm{D} / \mathrm{E}$ favors the mitigation of the endogeneity's risk, which represent one of the main criticisms in corporate governance studies (Li 2016).

\section{Results}

A correlation analysis (Table 3) was conducted (Lennox et al. 2012). The analysis reveals the absence of relationship higher than 0.600 between the observed variables. In this sense, following prior studies in accounting, heteroscedasticity has been excluded. Also, the correlation analysis provides first insights about the observed sample. In detail, we found that FAMILY_POWER and FAMILY_BOARD impact differently on the dependent variables. 
In particular, an insight was founded as regards ROE and ROA. Although management scholars usually adopt the two variables to evaluate financial performance, our results underline the exigence to evaluate the specific information related to the two financial ratios adequately. Specifically, ROE considers firms' equity, while ROA considers the total asset, representing the sum of equity and external funds. On a hand, the divergent findings suggest that FAMILY_POWER represents an enabler for achieving financial performance in firms with a high degree of financial independence. On the other hand, firms with a low degree of financial independency are negatively influenced by FAMILY_POWER. Thus, following as evidenced in prior studies about Italian economic systems, family members involvement within the organizations is typically characterized by firms with a high degree of share-concentration (Di Cagno et al. 2002).

Table 3. Correlation analysis.

\begin{tabular}{|c|c|c|c|c|c|c|c|c|c|c|c|c|c|c|}
\hline Variables & (1) & (2) & (3) & (4) & (5) & (6) & (7) & (8) & (9) & (10) & (11) & (12) & (13) & (14) \\
\hline (1) ROE & 1.000 & & & & & & & & & & & & & \\
\hline (2) ROA & 0.552 & 1.000 & & & & & & & & & & & & \\
\hline (3) FALCON & 0.356 & 0.415 & 1.000 & & & & & & & & & & & \\
\hline (4) CRIF & 0.510 & 0.569 & 0.712 & 1.000 & & & & & & & & & & \\
\hline (5) VADIS & -0.423 & -0.314 & -0.693 & -0.560 & 1.000 & & & & & & & & & \\
\hline (6) VPI & -0.423 & -0.314 & -0.693 & -0.560 & 1.000 & 1.000 & & & & & & & & \\
\hline (7) SIZE & -0.073 & -0.100 & 0.356 & 0.205 & -0.362 & -0.362 & 1.000 & & & & & & & \\
\hline (8) EQUITY & 0.124 & 0.093 & 0.679 & 0.402 & -0.639 & -0.639 & 0.854 & 1.000 & & & & & & \\
\hline (9) EMPLOYEES & 0.051 & 0.108 & 0.242 & 0.237 & -0.413 & -0.413 & 0.660 & 0.612 & 1.000 & & & & & \\
\hline (10) D/E & -0.450 & -0.268 & -0.467 & -0.279 & 0.414 & 0.414 & 0.077 & -0.338 & -0.116 & 1.000 & & & & \\
\hline (11) FAMILYFIRMS & -0.076 & -0.073 & -0.298 & -0.212 & 0.291 & 0.291 & -0.413 & -0.446 & -0.352 & 0.161 & 1.000 & & & \\
\hline (12) \%SHARES & 0.210 & -0.105 & -0.032 & -0.081 & 0.076 & 0.076 & -0.081 & -0.082 & -0.100 & -0.097 & -0.132 & 1.000 & & \\
\hline (13) FAMILY_POWER & 0.080 & -0.085 & -0.314 & -0.223 & 0.254 & 0.254 & -0.452 & -0.455 & -0.344 & 0.071 & 0.914 & 0.134 & 1.000 & \\
\hline (14) FAMILY_BOARD & 0.090 & 0.008 & -0.191 & -0.089 & 0.080 & 0.080 & -0.322 & -0.290 & -0.248 & 0.071 & 0.830 & -0.107 & 0.760 & 1.000 \\
\hline
\end{tabular}

Finally, five regressions (Table 4) were cnducted in order to evaluate the different implications related to the involvement of family members in tourism enterprises. The results provide interesting insights into the role covered by family members within organizations. In particular, despite the fact that the Italian context is characterized by a high degree of interlinkages between firms' ownership and corporate governance (Catuogno et al. 2018; Di Cagno et al. 2002; Pellicelli 2016), the data reveals the existence of differences caused by the different roles covered by family members in the organization. Also, despite the dependent variables used within the study regarding financial ratios characterized by different focus, the results reveal similarities and differences.

The analysis highlights that FAMILY_FIRMS negatively impacts ROE $(\beta=-46.264)$ and positively on VADIS $(\beta=2.092)$. The two results underline that family firms that operate in the tourism sector are more exposes to the risks of financial default than nonfamily firms.

The analysis of the ROE shown that Italian firms that operate in the tourism sector are undercapitalized. As evidenced in prior studies, this evidence confirms the relationship between family firms orientation toward external funding (Lappalainen and Niskanen 2013). In fact, family business are more oriented to finance their investments through their internal resources. Thus, the risks of financial default is higher due to the lack of orientation toward alternative financial mechanisms such as factoring and leasing.

Although the concept of bankruptcy's risks requires an in-depth analysis of different dynamics (Pizzi et al. 2020), this evidence is confirmed by the score assigned to VADIS. In fact, despite the fact that the analyses of the traditional financial ratios could be useful proxies to evaluate the financial dynamics of an organziations, the concept of financial distress requires a holistic approach based on a set of multidimensional indicators (Pizzi et al. 2020). An example that underline this evidence is represented by the exclusion from the ROE of the external funds. In this sense, the similarities between the two indicators do not represent an obvious relationship.

The results related to the variable FAMILY_POWER suggest that family member involvement within the BoD (FAMILY_BOARD) positively impacts ROE $(\beta=0.321)$. This 
evidence can be related to the family members' need to operate through mechanisms able to repair and maintain the capital over the time. In fact, as evidenced by many authors, one of the main differences between family business and public companies is represented by the long-run orientation (Di Cagno et al. 2002; Sciascia et al. 2014; Mahto et al. 2020). Thus, the investments of financial resources or the involvement of new shareholders represent dynamics that negatively affect the generational turnover of an organization.

Table 4. Regression analysis.

\begin{tabular}{|c|c|c|c|c|c|}
\hline & (1) & (2) & (3) & (4) & (5) \\
\hline & ROE & ROA & FALCON & CRIF & VADIS \\
\hline SIZE & $\begin{array}{l}-0.612 \\
(4.160)\end{array}$ & $\begin{array}{c}-6.223^{* * *} \\
(1.405)\end{array}$ & $\begin{array}{c}-0.887^{* * *} \\
(0.196)\end{array}$ & $\begin{array}{c}-78.006^{* * * *} \\
(19.468)\end{array}$ & $\begin{array}{c}0.836^{* * *} \\
(0.219)\end{array}$ \\
\hline EQUITY & $\begin{array}{l}-1.446 \\
(2.685)\end{array}$ & $\begin{array}{c}3.736^{* * *} \\
(0.847)\end{array}$ & $\begin{array}{c}1.184^{* * *} \\
(0.118)\end{array}$ & $\begin{array}{c}71.808^{* * *} \\
(11.783)\end{array}$ & $\begin{array}{c}-0.967^{* * *} \\
(0.136)\end{array}$ \\
\hline EMPLOYEES & $\begin{array}{c}1.559 \\
(4.176)\end{array}$ & $\begin{array}{c}3.132 * * \\
(1.564)\end{array}$ & $\begin{array}{c}0.052 \\
(0.218)\end{array}$ & $\begin{array}{c}28.944 \\
(21.638)\end{array}$ & $\begin{array}{c}-0.405 \text { * } \\
(0.244)\end{array}$ \\
\hline $\mathrm{D} / \mathrm{E}$ & $\begin{array}{c}-0.873^{*} \\
(0.484)\end{array}$ & $\begin{array}{c}0.248 \\
(0.170)\end{array}$ & $\begin{array}{l}-0.016 \\
(0.024)\end{array}$ & $\begin{array}{l}4.975 * * \\
(2.359)\end{array}$ & $\begin{array}{c}-0.016 \\
(0.027)\end{array}$ \\
\hline FAMILY_FIRMS & $\begin{array}{c}-46.264^{* * * *} \\
(13.917)\end{array}$ & $\begin{array}{c}0.270 \\
(4.972)\end{array}$ & $\begin{array}{l}-0.021 \\
(0.692)\end{array}$ & $\begin{array}{l}-57.822 \\
(68.797)\end{array}$ & $\begin{array}{c}2.092^{* * *} \\
(0.771)\end{array}$ \\
\hline \%SHARES & $\begin{array}{c}0.018 \\
(0.106)\end{array}$ & $\begin{array}{c}0.057 \\
(0.037)\end{array}$ & $\begin{array}{l}0.009^{*} \\
(0.005)\end{array}$ & $\begin{array}{l}-0.035 \\
(0.513)\end{array}$ & $\begin{array}{c}0.005 \\
(0.006)\end{array}$ \\
\hline FAMILY_POWER & $\begin{array}{c}0.321 \text { ** } \\
(0.147)\end{array}$ & $\begin{array}{l}-0.046 \\
(0.053)\end{array}$ & $\begin{array}{l}-0.003 \\
(0.007)\end{array}$ & $\begin{array}{c}0.306 \\
(0.739)\end{array}$ & $\begin{array}{c}-0.012 \\
(0.008)\end{array}$ \\
\hline FAMILY_BOARD & $\begin{array}{c}23.000^{* * * *} \\
(6.957)\end{array}$ & $\begin{array}{l}4.680^{*} \\
(2.578)\end{array}$ & $\begin{array}{c}0.284 \\
(0.358)\end{array}$ & $\begin{array}{c}44.284 \\
(35.646)\end{array}$ & $\begin{array}{c}-1.067^{* *} \\
(0.430)\end{array}$ \\
\hline _cons & $\begin{array}{c}22.193 \\
(22.597)\end{array}$ & $\begin{array}{c}14.703 \text { * } \\
(8.083)\end{array}$ & $\begin{array}{c}2.274^{* *} \\
(1.125)\end{array}$ & $\begin{array}{c}670.888^{* * *} \\
(111.859)\end{array}$ & $\begin{array}{c}4.393^{* * *} \\
(1.252)\end{array}$ \\
\hline R-squared & 0.205 & 0.201 & 0.658 & 0.311 & 0.518 \\
\hline
\end{tabular}

In this sense, the adverse effects caused by FAMILY_FIRMS is partially moderated by FAMILY_POWER. In detail, an increase of the shares owned by the family positively impacts on ROE. Thus, the existence of minority shareholders represents a barrier to the implementation of an adequate organizational system (Martin et al. 2017; Saidat et al. 2019). As evidenced below, this relationship is related to the different approaches that distinguish family members from non-family shareholders. On one hand, the first group is interested in maximizing the family interests through their activities. On the other hand, non-family members are driven by purposes inspired by the need to achieve capital gain from their investments. Thus, the divergences between the two orientation negatively impact on the implementation of adequate business strategies.

Finally, FAMILY_BOARD positively impacts on ROE $(\beta=23.00)$, ROA $(\beta=4.680)$ and negatively on VADIS ( $\beta=4.393$ ). Combining these three indicators highlights the enabling role covered by family members in firms characterized by an organizational system inspired by the so-called Modello padronale. In this sense, the convergence between ownership and corporate governance could favor the development of strategies characterized by the highest degree of effectiveness.

According to this evidence, the analysis of the impacts related to the involvement of family members in Italian tourism enterprises represents a complex activity. The analysis reveals divergent findings related to the existence of differences caused by the different business model adopted by tourism enterprises. We found that family firms are less profitable than non-financial firms in the tourism sector. On the other hand, we found that firms with a high percentage of shares owned by family members and decision-making processes represent signals of profitability. Thus, the comprehension of the phenomenon could be related to the cultural characteristics of the Italian systems. In detail, several authors discussed the Italian model based on firms with a high degree of ownership 
concentration and directly managed by shareholders. In this sense, the tourism sector analysis highlights the suitability of this model within a traditional sector characterized by the centrality of family firms (Giaccio et al. 2018; Peters 2005).

\section{Conclusions}

The present work, framed in the vein of managerial literature that investigates the discriminating performance of hotel companies focused on the analysis of the economictype performance of Italian Hotels. In particular, we focused our analysis on the impacts related to the presence of family members in ownership and corporate governance. In this sense, we have extended the scientific knowledge about a phenomenon widely spread in Italy (Banca d'Italia 2018).

Our study's theoretical implications consist of analyzing the role covered by family firms within the tourism sector. In detail, we found that the so-called modello padronale represents the most suitable business model for Italian hotels. In particular, the analysis reveals that family firms perform better than non-family firms. Furthermore, our insights are also useful for policymakers. The provision of incentives to support family firms during the financial crisis could represent an enabling factor for social wellbeing development.

Our study's political implications are represented by the opportunity for policymakers to regulate the tourism sector. As evidenced by our study, ownership structure represents a proxy useful to evaluate firms' dynamics. Thus, the provision of fiscal policies or the direct investments in family firms will represent a strategic driver for policymakers to favour the development of the tourism sector.

However, the comprehension of the dynamics that impact financial performance cannot be analyzed without an in-depth analysis of the organizations. In this sense, the risks of endogeneity caused by corporate governance behaviors require a cautionary approach based on evaluating the financial and non-financial dynamics that characterize each organization (Coles and Li 2012a, 2012b). In this sense, the comprehension of the phenomenon requires both the adoption of more sophisticated variables and a different methodological approach.

The study presents some limitations. One of the main limitations is represented by the recent collapse of the Italian tourism sector caused by COVID-19. In this sense, the empirical analysis of the impacts caused by COVID-19 could represent an interesting future research direction. Furthermore, our analysis considered only Italian hotels. Thus, the analysis of other economic systems could provide different results.

Finally, our analysis was built on a single fiscal year. Although the results collected can be useful for the development of new knowledge about the Italian context, future research will evaluate the phenomenon through alternative methods such as panel data analysis and Structural Equation Models (SEM).

Author Contributions: All authors contributed equally to this work. All authors have read and agreed to the published version of the manuscript.

Funding: This research received no external funding.

Conflicts of Interest: The authors declare no conflict of interest.

\section{References}

Aguilera, Ruth V., and Rafel Crespi-Cladera. 2012. Firm family firms: Current debates of corporate governance in family firms. Journal of Family Business Strategy 3: 66-69. [CrossRef]

Alola, Andrew A., Simplice A. Asongu, and Uju V. Alola. 2020. House prices and tourism development in Cyprus: A contemporary perspective. Journal of Public Affairs 20: e2035. [CrossRef]

Azila-Gbettor, Edem M., Ben Q. Honyenuga, Marta M. Berent-Braun, and Ad Kil. 2018. Structural aspects of corporate governance and family firm performance: A systematic review. Journal of Family Business Management 8: 306-30. [CrossRef]

Bagnaresi, Davide, Francesco Maria Barbini, and Patrizia Battilani. 2019. Organizational change in the hospitality industry: The change drivers in a longitudinal analysis. Business History. [CrossRef]

Banca d'Italia. 2018. Turismo in Italia Numeri e Potenziale di Sviluppo. Roma: Banca d'Italia. 
Bartoloni, Marzio. 2020. Il turismo resta il petrolio d'Italia: «Oltre 40 miliardi nel 2019, ora diversificare»-Il Sole 24 ORE. Available online: https:/ / www.ilsole24ore.com/art/il-turismo-resta-petrolio-d-italia-oltre-40-miliardi-2019-ora-diversificare-ACTKjOCB (accessed on 2 November 2020).

Besanko, David, David Dranove, and Mark Shanley. 2000. Sustaining Competitive Advantage. New York: Jhon Wiley.

Brenes, Esteban R., Kryssia Madrigal, and Bernardo Requena. 2009. Corporate governance and family business performance. Journal of Business Research 64: 280-85. [CrossRef]

Brent Ritchie, J. R., and Geoffrey Ian Crouch. 2004. The competitive destination: A sustainable tourism perspective. Choice Reviews Online 41: 41-6012. [CrossRef]

Brida, Juan Gabriel, and Wiston Adrian Risso. 2010. Tourism as a determinant of long-run economic growth. Journal of Policy Research in Tourism, Leisure E Events 2: 14-28. [CrossRef]

Caputo, Fabio, Barbara Livieri, and Andrea Venturelli. 2014. Intangibles and Value Creation in Network Agreements: Analysis of Italian firms. Management Control, 45-70. [CrossRef]

Caputo, Andrea, Giacomo Marzi, Massimiliano Matteo Pellegrini, and Riccardo Rialti. 2018. Conflict management in family businesses: A bibliometric analysis and systematic literature review. International Journal of Conflict Management 29: 519-42. [CrossRef]

Casillas, Jose C., Ana M. Moreno-Menéndez, José L. Barbero, and Eric Clinton. 2019. Retrenchment Strategies and Family Involvement: The Role of Survival Risk. Family Business Review. 32: 58-75. [CrossRef]

Catuogno, Simona, Claudia Arena, Alessandro Cirillo, and Luca Pennacchio. 2018. Exploring the relation between family ownership and incentive stock options: The contingency of family leadership, board monitoring and financial crisis. Journal of Family Business Strategy 9: 59-72. [CrossRef]

Chung, Kyoo Yup. 2000. Hotel room rate pricing strategy for market share in oligopolistic competition-Eight-year longitudinal study of super deluxe hotels in Seoul. Tourism Management 21: 135-45. [CrossRef]

Coles, Jeffrey L., and Zhichuan Frank Li. 2012a. An Empirical Assessment of Empirical Corporate Finance. Available online: https:/ / ssrn.com/abstract=1787143 (accessed on 20 January 2021).

Coles, Jeffrey L., and Zhichuan Li. 2012b. Managerial Attributes, Incentives, and Performance. Available online: https:/ /papers.ssrn. com/sol3/papers.cfm?abstract_id=1680484 (accessed on 20 January 2021).

Colli, Andrea. 2003. The History of Family Business, 1850-2000. Cambridge: Cambridge University Press.

Cucculelli, Marco, and Dimitri Storai. 2015. Family firms and industrial districts: Evidence from the Italian manufacturing industry. Journal of Family Business Strategy 6: 234-46. [CrossRef]

De Massis, Alfredo, Josip Kotlar, Giovanna Campopiano, and Lucio Cassia. 2013. Dispersion of family ownership and the performance of small-to-medium size private family firms. Journal of Family Business Strategy 4: 166-75. [CrossRef]

Di Cagno, Nicola, Stefano Adamo, and Francesco Giaccari. 2002. Lezioni di economia aziendale. Bari: Cacucci.

Fama, Eugene F., and Michael C. Jensen. 1983. Agency Problems and Residual Claims. The Journal of Law and Economics 26: 327-49. [CrossRef]

Fama, Eugene F., and Michael C. Jensen. 2019. Separation of ownership and control. In Corporate Governance: Values, Ethics and Leadership. Abingdon: Taylor and Francis, pp. 163-88, ISBN 9781315191157.

Garrigós-Simón, Fernando J., Daniel Palacios Marqués, and Yeamduan Narangajavana. 2005. Competitive strategies and performance in Spanish hospitality firms. International Journal of Contemporary Hospitality Management 17: 22-38. [CrossRef]

Getz, Donald, and Jack Carlsen. 2005. Family business in tourism. State of the art. Annals of Tourism Research 32: 237-58. [CrossRef]

Giaccio, Vincenzo, Agostino Giannelli, and Luigi Mastronardi. 2018. Explaining determinants of Agri-tourism income: Evidence from Italy. Tourism Review 73: 216-29. [CrossRef]

Harris, Phil, and Ozlem Ozdemir. 2020. Turkish delight a public affairs study on family business: The influence of owners in the entrepreneurship orientation of family-owned businesses. Journal of Public Affairs 20: e2082. [CrossRef]

Illy, Andrea. 2019. Sostenibilità, felicità, net present value e dintorni. Sinergie Italian Journal of Management 37: 35-40. [CrossRef]

Jolliffe, Lee, and Regena Farnsworth. 2003. Seasonality in tourism employment: Human resource challenges. International Journal of Contemporary Hospitality Management 15: 312-16. [CrossRef]

Kang, Kyung Ho, Seoki Lee, and Chang Huh. 2010. Impacts of positive and negative corporate social responsibility activities on company performance in the hospitality industry. International Journal of Hospitality Management 29: 72-82. [CrossRef]

Kim, Hong-bumm, and Woo Gon Kim. 2005. The relationship between brand equity and firms' performance in luxury hotels and chain restaurants. Tourism Management 26: 549-60. [CrossRef]

Kusluvan, Salih, Zeynep Kusluvan, Ibrahim Ilhan, and Lutfi Buyruk. 2010. The Human Dimension. Cornell Hospitality Quarterly 51: 171-214. [CrossRef]

Lappalainen, Jaana, and Mervi Niskanen. 2013. Behavior and attitudes of small family firms towards different funding sources. Journal of Small Business E Entrepreneurship 26: 579-99. [CrossRef]

Lennox, Clive S., Jere R. Francis, and Zitian Wang. 2012. Selection models in accounting research. The Accounting Review 87: 589-616. [CrossRef]

Leone, Andrew J., Miguel Minutti-Meza, and Charles E. Wasley. 2019. Influential observations and inference in accounting research. The Accounting Review 94: 337-64. [CrossRef]

Li, Frank. 2016. Endogeneity in CEO power: A survey and experiment. Investment Analysts Journal 45: 149-62. [CrossRef] 
Lozano, M. Belén, Beatriz Martínez, and Julio Pindado. 2016. Corporate governance, ownership and firm value: Drivers of ownership as a good corporate governance mechanism. International Business Review 25: 1333-43. [CrossRef]

Lude, Maximilian, and Reinhard Prügl. 2018. Why the family business brand matters: Brand authenticity and the family firm trust inference. Journal of Business Research 89: 121-34. [CrossRef]

Mahto, Raj V., Gautam Vora, William C. McDowell, and Dmitry Khanin. 2020. Family member commitment, the opportunity costs of staying, and turnover intentions. Journal of Business Research 108: 9-19. [CrossRef]

Martin, Geoffrey, Luis R. Gómez-Mejía, Pascual Berrone, and Marianna Makri. 2017. Conflict between Controlling Family Owners and Minority Shareholders: Much Ado about Nothing? Entrepreneurship Theory and Practice 41: 999-1027. [CrossRef]

Martinez Jimenez, Rocio. 2009. Research on Women in Family Firms. Family Business Review 22: 53-64. [CrossRef]

McGuire, Jean, Sandra Dow, and Bakr Ibrahim. 2012. All in the family? Social performance and corporate governance in the family firm. Journal of Business Research 65: 1643-50. [CrossRef]

Meo, Muhammad, Solomon Nathaniel, Ghulam Shaikh, and Anoop Kumar. 2020. Energy consumption, institutional quality and tourist arrival in Pakistan: Is the nexus (a)symmetric amidst structural breaks? Journal of Public Affairs e2213. [CrossRef]

Mubangizi, Betty C., and David Mwesigwa. 2019. Enhancing Local Economic Development through tourism: Perspectives from a cohort of Got Ngetta rock climbers in Mid-North Uganda. African Journal of Hospitality, Tourism and Leisure. Available online: file:/ / C:/Users/MDPI/AppData/Local/Temp/article_74_vol_8_5_2019_ukzn.pdf (accessed on 22 January 2021).

Newell, Graeme, and Ross Seabrook. 2006. Factors influencing hotel investment decision making. Journal of Property Investment $\mathcal{E}$ Finance 24: 279-94. [CrossRef]

Nissim, Doron, and Stephen H. Penman. 2001. Ratio analysis and equity valuation: From research to practice. Review of Accounting Studies 6: 109-54. [CrossRef]

Nordqvist, Mattias, Pramodita Sharma, and Francesco Chirico. 2014. Family Firm Heterogeneity and Governance: A Configuration Approach. Journal of Small Business Management 52: 192-209. [CrossRef]

Palmi, Pamela, Fabio Caputo, and Mario Turco. 2016. Changing Movie! Film Commissions as drivers for creative film industries: The Apulia Case. ENCATC Journal of Cultural Management and Policy 6: 56-72.

Pandikasala, Jijin, Iti Vyas, and Nithin Mani. 2020. Do financial development drive remittances? Empirical evidence from India. Journal of Public Affairs 7: 290-304. [CrossRef]

Pellicelli, Michela. 2016. Dall'Impresa Padronale al Value Based Management. Sei Modelli Interpretativi di un'Inevitabile Evoluzione. Economia Aziendale Online 7: 43-60. [CrossRef]

Peters, Mike. 2005. Succession in tourism familiy business: The motivation of succeeding family members. Tourism Review 60: $12-18$. [CrossRef]

Pizzi, Simone, Fabio Caputo, and Andrea Venturelli. 2020. Does it pay to be an honest entrepreneur? Addressing the relationship between sustainable development and bankruptcy risk. Corporate Social Responsibility and Environmental Management 27: 1478-86. [CrossRef]

Rai, Rajnish Kumar. 2016. A Co-opetition-Based Approach to Value Creation in Interfirm Alliances. Journal of Management 42: 1663-99. [CrossRef]

Revilla, Antonio J., Ana Perez-Luno, and María Jesús Nieto. 2016. Does Family Involvement in Management Reduce the Risk of Business Failure? The Moderating Role of Entrepreneurial Orientation. Family Business Review 29: 365-79. [CrossRef]

Rosato, Pier Felice, Andrea Caputo, Donatella Valente, and Simone Pizzi. 2021. 2030 Agenda and sustainable business models in tourism: A bibliometric analysis. Ecological Indicators 121. [CrossRef]

Saidat, Zaid, Mauricio Silva, and Claire Seaman. 2019. The relationship between corporate governance and financial performance: Evidence from Jordanian family and non-family firms. Journal of Family Business Management 9: 54-78. [CrossRef]

Saif Ul Islam, Muhammad, Muhammad Saeed Meo, and Muhammad Usman. 2020. The relationship between corporate investment decision and firm performance: Moderating role of cash flows. Journal of Public Affairs. [CrossRef]

Sainaghi, Ruggero. 2004. La gestione strategica dei distretti turistici. Milano: CUSL.

Sakawa, Hideaki, and Naoki Watanabel. 2019. Family control and ownership monitoring in Stakeholder-oriented corporate governance. Management Decision 57: 1712-28. [CrossRef]

Santarelli, Enrico, and Francesca Lotti. 2005. The survival of family firms: The importance of control and family ties. International Journal of the Economics of Business 12: 183-92. [CrossRef]

Sciascia, Salvatore, Pietro Mazzola, and Franz W. Kellermanns. 2014. Family management and profitability in private family-owned firms: Introducing generational stage and the socioemotional wealth perspective. Journal of Family Business Strategy 5: 131-37. [CrossRef]

Shapiro, Susan P. 2005. Agency theory. Annual Review of Sociology 31: 263-84. [CrossRef]

Sharma, Piyush, Ivy S. N. Chen, and Sherriff T. K. Luk. 2018. Tourist Shoppers' Evaluation of Retail Service: A Study of Cross-Border Versus International Outshoppers. Journal of Hospitality \& Tourism Research 42: 392-419. [CrossRef]

Song, Haiyan, and Gang Li. 2008. Tourism demand modelling and forecasting-A review of recent research. Tourism Management 29: 203-20. [CrossRef]

Stanley, Laura J., Remedios Hernández-Linares, María Concepción López-Fernández, and Franz W. Kellermanns. 2019. A Typology of Family Firms: An Investigation of Entrepreneurial Orientation and Performance. Family Business Review 32: 174-94. [CrossRef] 
Stone, Mary, and John Rasp. 1991. Tradeoffs in the Choice between Logit and OLS for Accounting Choice Studies. Accounting Review 66: $170-87$.

Van den Berghe, Lutgart A. A., and Steven Carchon. 2003. Agency relations within the family business system: An exploratory approach. Corporate Governance: An International Review 11: 171-79. [CrossRef]

Van Looy, Amy, and Aygun Shafagatova. 2016. Business process performance measurement: A structured literature review of indicators, measures and metrics. SpringerPlus 5: 1-24. [CrossRef]

Venkatraman, Natarjan, and Vasudevan Ramanujam. 1986. Measurement of Business Performance in Strategy Research: A Comparison of Approaches. Academy of Management Review 11: 801-14. [CrossRef]

Venturelli, Andrea, Salvatore Principale, Lorenzo Ligorio, and Simona Cosma. 2020. Walking the talk in family firms. An empirical investigation of CSR communication and practices. Corporate Social Responsibility and Environmental Management. [CrossRef]

Yeung, Ping-Kwong, and Chung-Ming Lau. 2005. Competitive actions and firm performance of hotels in Hong Kong. International Journal of Hospitality Management 24: 611-33. [CrossRef]

Zhou, Yanhong, Kudzayi Maumbe, Jinyang Deng, and Steven W. Selin. 2015. Resource-based destination competitiveness evaluation using a hybrid analytic hierarchy process (AHP): The case study of West Virginia. Tourism Management Perspectives 15: 72-80. [CrossRef] 